УДК $811.161 .2 ' 373.611$

О. Л. Білка

\title{
БАГАТОКОМПОНЕНТНІ БІОЛОГІЧНІ ТЕРМІНИ ВТОРИННОЇ НОМІНАЦІї
}

Білка О. Л. Багатокомпонентні біологічні терміни вторинної номінації.

У статті розглянуто багатокомпонентні біологічні терміни вторинної номінації. У межах трикомопнентних біологічних термінів виокремлено чотири структурно-семантичні типи:»прикметник + прикметник + іменник», «прикметник + іменник + прикметник», «іменник + прикметник + іменник», «прикметник + іменник + іменник». 3'ясовано, що чотиричленні біологічні терміносполучення 3-поміж багатокомпонентних термінів становлять меншість.

Ключові слова: вторинна номінація, аналітичний термін, компонент із переносним значенням, компонент із прямим значенням.

Белка Е. Л. Многокомпонентные биологические термины вторичной номинации.

В статье рассмотрены многокомпонентные биологические термины вторичной номинации. Среди трехкомпонентных биологических терминов выделены четыре структурно-семантические типы: «прилагательное + прилагательное + существительное», «прилагательное + существительное + прилагательное», «существительное + прилагательное + существительное», «прилагательное + существительное + существительное». Выяснено, что четырехчленные биологические словосочетания среди многокомпонентных терминов составляют меньшинство.

Ключевые слова: вторичная номинация, аналитический термин, компонент с переносным значением, компонент с прямым значением

Bilka O. L. Multicomponent biological terms of secondary nomination.

The article deals with multi-biological terms secondary category. Within threecomponental biological terms specifically mentioned four structural and semantic types: «adjective + adjective + noun», «adjective + noun + adjective», «noun + adjective + noun», «adjective + noun + noun». It was found that biological chotyrychlenni terminospoluchennya among multi-terms are a minority.

Key words: secondary nomination, analytical terms, a component of figuratively, a component of direct value. 
У розвитку галузевих термінологій дослідники виокремлюють дві протилежні тенденції. Суть першої полягає в прагненні до стислості, економії мовних засобів, що зумовлює утворення термінів-слів і термінів-скорочень. Друга тенденція виявляється в семантичній регулярності, тобто у відображенні в структурі терміна родо-видових та інших відношень, унаслідок чого виникають терміни-складні слова і терміни-словосполучення [2, с. 94].

У складі аналітичних біологічних термінів української мови функціонують три- i чотирикомпонентні терміносполучення, один iз складників яких має переносне значення. Це засвідчує всепроникність вторинної номінації, оскільки, ставши одним із способів термінотворення, вона проникає в усі структурні види спеціальних назв, зокрема в багатокомпонентні [1, c. 18]. Важливо зазначити, що позиція метафоричного та метонімічного складника в таких словосполученнях може бути різною: метафорою чи метонімією виражають як домінантний, так і поширювальний компонент терміносполучення.

Специфіку лексико-семантичного наповнення тричленних аналітичних біологічних терміносполучень української мови становить те, що їх сформували три частиномовні компоненти - іменник i два прикметники та прикметник і два іменники. 3-поміж них виокремлюємо чотири типи. Перший тип репрезентовано структурою «прикметник + прикметник + іменник». Характерною особливістю цього типу трикомпонентних терміносполучень $\epsilon$ те, що в ньому семантичне перенесення зазнав перший атрибутивний компонент. Тому творення термінів цього типу відбувається за однією термінотвірною моделлю.

TM-1: «компонент із переносним значенням + компонент із прямим значенням + компонент із прямим значенням». Пор.: ієрогліфовий африканський пітон, вуальний сріблястий кріль, левовий золотистий тамарин, тигровий далекосхідний вуж, коробчаста каролінська черепаха, чубата африканська зозуля та ін. Так, термін ієрогліфовий африканський пітон - це «велика неотруйна змія родини удавових, щзо має складний, схожий на ієрогліфи, малюнок на тілі». Загальновживане значення компонента з переносним значенням ієрогліфовий: «той, щзо стосується ієрогліфа - фігурного знака в системі ідеографічного письма, щуо позначає поняття, склад або звук мови». Перший компонент із прямим значенням африканський вказує на місце поширення плазуна, другий пімон - на велику неотруйну змію. У значенні біологічного терміна виокремлюємо семи: «змія», «що має складний, схожий на ієрогліфи, малюнок на тілі». У значенні компонента 3 переносним значенням переважає сема «фігурний знак». Семантичне перенесення відбулося за зовнішньою подібністю в напрямку: фігурний знак $\rightarrow$ плазун.

Другий тип тричленних аналітичних біологічних терміносполучень утворюють структури «прикметник + іменник + прикметник» за однією термінотвірною моделлю. 
TM-1: «компонент із переносним значенням + компонент iз переносним значенням + компонент із прямим значенням «. Напр.: курячі очки польові, вовче тіло болотне, павине око нічне тощо. Термін курячі очки польові має дефініцію: «однорічна трав'яниста рослина з чорними крапками на листках, щзо нагадують очі курки». Загальновживане значення першого компонента $з$ переносним значенням курячі (курячий): «той, щзо належить куризі - свійській птиці, яку розводять на м’ясо $і$ для одержання яєць». Загальновживане значення другого компонента 3 переносним значенням очки (зменш.-пестл. до очі): «орган зору в людини, всіх хребетних та деяких безхребетних тварин». Компонент із прямим значенням польовий вказує на місце зростання рослини. Ономасіологічною базою перенесення назви стало значення обох компонентів із переносним значенням, у яких переважають семи: «свійська птиця» та «орган зору». У значенні біологічного терміна домінують семи: «рослина» «з чорними крапками на листках», «що схожі на очі курки». Перенесення відбулося за зовнішньою подібністю в напрямку: орган зору свійської птиці $\rightarrow$ рослина.

Третій тип тричленних аналітичних біологічних терміносполук формують структури «іменник + прикметник + іменник» за однією термінотвірною моделлю.

TM-1: «компонент із прямим значенням + компонент із переносним значенням + компонент із переносним значенням «. Напр.: адіант венерин волос, бігнонія котячі кігті, бражник мертва голова, дерево гарматних ядер, птілій страусове перо, дивина ведмеже вухо та ін. Так, термін дерево гарматних ядер позначає: «азійське дерево з ідеально круглими плодами, щзо дійсно нагадують гарматні ядра». Загальновживане значення першого компонента 3 переносним значенням гарматних (гарматний): «той, щуо стосується гармати - артилерійської довгоствольної вогнепальної зброї з похилою траєкторією, призначеної для ураження живої сили $i$ бойової техніки противника, руйнування оборонних споруд». Загальновживане значення другого компонента з переносним значенням ядер (яоро): «кулястий суиільний снаряд ударної дії у гладкоствольній артилерії». Компонент із прямим значенням дерево називає багаторічну рослину 3 твердим стовбуром і гіллям, що утворює крону. Ономасіологічною базою номінації біологічного поняття стало значення обох компонентів із переносним значенням, у яких домінують семи: «артилерійська зброя» та «кулястий снаряд». У значенні біологічного терміна наявні семи: «дерево», «плоди якого схожі на гарматні ядра». Перенесення відбулося за зовнішньою подібністю в напрямку: військова зброя $\rightarrow$ рослина.

Четвертий тип тричленних аналітичних терміносполучень формують структури «прикметник + іменник + іменник» за однією термінотвірною моделлю. 
TM-1: «компонент із прямим значенням + компонент із прямим значенням + компонент із переносним значенням». У межах цього типу функціонує обмежена кількість термінів: золотиста рибка комета, золота рибка телескоп тощо. Термін золотиста рибка комета має дефініцію: «прісноводна риба родини коропових золотистого забарвлення, щзо має довгасте тіло, схоже на комету». Загальновживане значення компонента 3 переносним значенням комета: «небесне тіло, щзо має яскраве ядро й туманну оболонку, від якої тягнеться довга смуга світла, щуо нагадує хвіст». Перший компонент із прямим значенням золотиста означає колір, схожий на золото, другий рибка позначає водяну хребетну тварину 3 непостійною темпертурою тіла, яка дихає жабрами і має плавці та шкіру, звичайно вкриту лускою. Ономасіологічною базою для виникнення біологічного терміна стало значення компонента з переносним значенням, у семантичній структурі якого наявна сема «небесне тіло». Біологічний термін складається із сем: «риба» «золотистого забарвлення», «схожа на комету». Перенесення відбулося за зовнішньою подібністю в напрямку: небесне тіло $\rightarrow$ риба.

Частота вживання чотирикомпонентних словосполучень дуже низька. Серед них виокремлюємо два типи термінів. Перший тип чотирикомпонентних аналітичних терміносполук вторинної номінації в біологічній термінології представлений структурою «прикметник + іменник + прикметник + іменник». Аналітичні терміни цього типу утворюються за однією термінотвірною моделлю.

TM-1: «компонент із прямим значенням + компонент із прямим значенням + компонент із прямим значенням + компонент із переносним значенням». За цією моделлю утворилися біологічні терміни на взірець золотиста рибка червона шапочка: «прісноводна риба родини коропових золотистого забарвлення із червоною плямою на голові, щзо схожа на маленьку шапку». Загальновживане значення компонента 3 переносним значенням шапочка (зменш.-пестл. до шапка): «головний убір». Компонент із прямим значенням золотиста означає колір золота, другий рибка позначає водяну хребетну тварину з непостійною темпертурою тіла, яка дихає жабрами і має плавці та шкіру, звичайно вкриту лускою, третій червона - колір крові. Ономасіологічною базою для виникнення терміна стало значення компонента 3 переносним значенням, у семантичній структурі якого наявна сема «головний убір». Значення біологічного терміна складається із сем: «риба» «золотистого забарвлення» «із червоною плямою на голові», «що схожа на шапку». Перенесення відбулося за зовнішньою подібністю в напрямку: головний убір $\rightarrow$ риба.

Другий тип репрезентовано структурою «іменник + прикметник + прикметник + іменник». Терміни у межах цього типу утворилися за двома термінотвірними моделями. 
TM-1: «компонент із прямим значенням + компонент із прямим значенням + компонент із прямим значенням + компонент із переносним значенням». Пор.: редька китайська червоне сери̧е, перецьь гіркий китайська квітка тощо. Так, біологічний термін редька китайська червоне серце має дефініцію: «китайський сорт редьки з унікальними плодами: зеленекувато-білі зовні і яскраво-червоні всередені, які схожі на сериее». Загальновживане значення компонента 3 переносним значенням серце: «центтальний орган кровоносної системи у вигляді м'язового мімка, ритмічні скорочення якого забезпечують кровообіг». Компонент із прямим значенням редька вказує на дворічну овочеву рослину родини

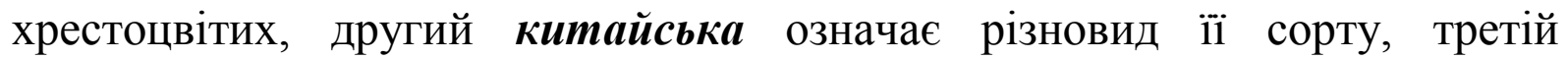
червоне - колір крові. Ономасіологічною базою для виникнення терміна стало значення компонента з переносним значенням, у якому домінує сема «орган кровоносної системи». У біологічному терміні переважають семи: «сорт редьки», «плоди якого нагадують серце». Перенесення відбулося за зовнішньою подібністю в напрямку: орган кровоносної системи $\rightarrow$ рослина.

ТМ-2: «компонент із прямим значенням + компонент із прямим значенням + компонент із переносним значенням + компонент iз переносним значенням». Ця модель представлена біологічним терміном редька китайська вогниста куля, що має дефініцію: «китайський сорт редьки з насиченими рожевими плодами, схожими на кулю». Загальновживане значення першого компонента з переносним значенням вогниста (вогнистий): «кольором подібний до вогню» Загальновживане значення другого компонента 3 переносним значенням куля: «геометричне тіло, утворене обертанням кола навколо свого діаметра». Компонент із прямим значенням редька позначає дворічну овочеву рослину рослини родини хрестоцвітих, другий китайська - різновид іiі сорту. Ономасіологічною базою для виникнення терміна стало значення обох компонентів із переносним значенням, у якому домінують семи: «геометрична фігура», «кольором подібна до вогню». У компонентній структурі значення біологічного терміна зафіксовані семи: «сорт редьки», «Плоди якого схожі на кулю». Перенесення відбулося за зовнішньою подібністю в напрямку: геометрична фігура, кольором подібна до вогню $\rightarrow$ рослина.

Отже, з-поміж багатокомпонентних терміносполучень вторинної номінації в біологічній термінології кількісно переважають тричленні 3 одним або двома метафоризованими компонентами. Чотирикомпонентні аналітичні терміносполучення становлять меншість і є непродуктивними.

\section{Література}

1. Винник О. П. Метафоричні процеси у формуванні української економічної лексики : автореф. дис. на здобуття наук. ступеня канд. філол. наук : спец. 10.02 .01 «Українська мова» О. П. Винник. Харків, 2007. - 20 с.

2. Козак Л. В. Українська електротехнічна термінологія (словотвірний аспект) : дисертація на здобуття наук. ступеня канд. філол. наук : спец. 10.02.01 «Українська мова» Людмила Володимирівна Козак. - Дніпропетровськ, 2000. - 171 с.
( О. Л. Білка, 2011. 